\title{
Effect of sprouting and temperature on crudivorism diet
}

\author{
M. C. de Souza ${ }^{1}$, C. B. Fiori ${ }^{1}$, S. G. C. Brazaca ${ }^{2}$, K. C. P. Mclellan ${ }^{3}$, A. C. Roder ${ }^{1}$ \\ and C. T. Dos Santos \\ ${ }^{1}$ Nutrition Course, Faculty Heath Sciences Methodist University of Piracicaba, SP/Brazil, ${ }^{2}$ Luiz de Queiroz Agriculture \\ School, University of Sao Paulo, Piracicaba, SP/Brazil and ${ }^{3}$ School of Nutrition, Pontificia Catholic University, Campinas, \\ SP/Brazil
}

The crudivorism diet consists of foods that are exclusively raw. These food habits can reduce the risks of metabolic diseases, CVD, arterial hypertension, colon cancer, diverticular disease of the colon, kidney stones and gallstones. Nevertheless, crudivorism are associated with high risks of deficiencies especially in children and pregnant women ${ }^{(1)}$.

The research aimed to verify the nutritional adequacy of a raw diet consisting of sprouted legumes cooked under three distinct temperatures. The four experimental diets studied were: basic diet + sprouted lentils + vegetable oil, basic diet + sprouted lentils + sprouted peanuts, basic diet + ungerminated lentils + vegetable oil, basic diet + ungerminated lentils + sprouted peanuts. All diets underwent the same chemical analyses for macronutrients after being either not cooked, cooked at 100,70 and $25^{\circ} \mathrm{C}$ for $5-10$ min in aluminium pots. Statistical analysis used $F$-test to analyse variance and the Tukey test was used to compare the means of the different diet formulations.

\begin{tabular}{|c|c|c|c|c|c|c|}
\hline \multirow[b]{2}{*}{ Insoluble fibre $(\%)$} & \multicolumn{2}{|c|}{$25^{\circ} \mathrm{C}$} & \multicolumn{2}{|c|}{$70^{\circ} \mathrm{C}$} & \multicolumn{2}{|c|}{$100^{\circ} \mathrm{C}$} \\
\hline & $0.52 *$ & 0.3 & $0.39 \dagger$ & 0.1 & $0.52 *$ & 0.3 \\
\hline Soluble fibre $(\%)$ & $1.04 *$ & 0.7 & $0.69 \dagger$ & 0.2 & $1.04 *$ & 0.7 \\
\hline $\mathrm{P}(\mathrm{mg} / \mathrm{g})$ & $1.05 \dagger$ & 0.3 & $1.08 \dagger$ & 0.2 & $1.17 *$ & 0.4 \\
\hline $\mathrm{K}(\mathrm{mg} / \mathrm{g})$ & $5.01 \dagger$ & 0.8 & $4.79 \dagger$ & 0.5 & $5.49^{\mathrm{I}}$ & 1.5 \\
\hline $\mathrm{Mg}(\mathrm{mg} / \mathrm{g})$ & $0.27 \dagger$ & 0.1 & $0.27 \dagger$ & 0.1 & $0.32 *$ & 0.1 \\
\hline $\mathrm{S}(\mathrm{mg} / \mathrm{g})$ & $0.68 \dagger$ & 0.2 & $0.69 \dagger$ & 0.1 & $0.73^{*}$ & 0.2 \\
\hline $\mathrm{Cu}(\mu \mathrm{g} / \mathrm{g})$ & $2.81 \dagger$ & 1.0 & $2.66 \dagger$ & 0.5 & $3.22 *$ & 1.0 \\
\hline $\mathrm{Fe}(\mu \mathrm{g} / \mathrm{g})$ & $27.84 \dagger$ & 7.9 & $25.68 \dagger$ & 6.5 & $32.63^{*}$ & 9.4 \\
\hline $\mathrm{Mn}(\mu \mathrm{g} / \mathrm{g})$ & $4.67 \dagger$ & 1.2 & $4.69 \dagger$ & 0.7 & $6.98^{*}$ & 1.10 \\
\hline $\mathrm{Zn}(\mu \mathrm{g} / \mathrm{g})$ & $11.22 \dagger$ & 2.6 & $11.27 \dagger$ & 2.6 & $12.13^{*}$ & 3.5 \\
\hline Dialysed $\mathrm{Fe}(\%)$ & $11.17 \dagger$ & 3.6 & $17.20 *$ & 5.5 & $12.86 \dagger$ & 4.1 \\
\hline Dial Fe $(\mathrm{mg} / \mathrm{kg})$ & $9.95 \dagger$ & 2.3 & $14.64 *$ & 3.9 & $11.50 \dagger$ & 3.9 \\
\hline Ascorbic Acid (mg/100g) & $19.88^{*}$ & 4.0 & $18.51 *$ & 2.7 & $19.26^{*}$ & 3.0 \\
\hline
\end{tabular}

$* \dagger$ Mean and SD for tree experiments according to temperature. Different letters in the means of the different temperatures indicate significant differences $(P<0.05)$.

One-hundred grams of the tested diets had an average of $556 \mathrm{~J}, 6.73 \mathrm{~g}$ of protein, $2.64 \mathrm{~g}$ of fat and $19.33 \mathrm{~g}$ of carbohydrate. Diets cooked at $25^{\circ} \mathrm{C}$ and $100^{\circ} \mathrm{C}$ have significantly different percentages and contents of dialysable Fe than those cooked at $70^{\circ} \mathrm{C}(P<0.05)$. Diets with ungerminated lentils had significantly higher percentages of soluble and insoluble fibres and mineral content than diets with sprouted lentils $(P<0.05)$. Mineral contents of the diets cooked at $25^{\circ} \mathrm{C}$ and $70^{\circ} \mathrm{C}$ are significantly different from those of the diets cooked at $100^{\circ} \mathrm{C}$ $(P<0.05)$ (Table 1). The highest mineral contents were found in diets cooked at $100^{\circ} \mathrm{C}$. One-hundred grams of the studied diets provide $36 \%$ of the dietary reference intakes of copper, $10 \%$ of $\mathrm{Fe}, 39 \%$ of $\mathrm{Mn}$ and $14 \%$ of $\mathrm{Zn}{ }^{(2)}$. The ascorbic acid contents did not vary significantly with cooking temperature.

Diets with sprouted lentils present significantly higher dialysable $\mathrm{Fe}$ and ascorbic acid contents than diets with ungerminated lentils $(P<0.05)$. Cooking changed the antinutrient, mineral, fibre and antioxidant contents of the diets and their centesimal composition.

1. Debry G. Diet peculiarities. Vegetarianism, veganism, crudivorism, macrobiotism (1991) Rev Prat 41, 967-972.

2. Dietary Reference Intakes: Elements (2009) Food and Nutrition Board. New York: National Academy of Sciences. Institute of Medicine. 